\title{
WMO publications
}

The World's Water: Is There Enough? (1997, 22 pp., $\$ 20.00$, paperbound, WMO No. 857, World Meteorological Organization, ISBN 92-63-10857-9). The focus of this brochure is to address the world's freshwater supply. The primary goals are to access the supply and determine the availability of and use of water resources. The booklet identifies the average annual runoff, the basis for assessing, global water withdrawal and consumption, water pollution, the water scarcity index, water and health, and a global water strategy. The document also includes a case study of the overexploitation of the Aral Sea.

The Global Climate System Review: Climate System Monitoring June 1991-November 1993 (1995, 150 pp., \$20.00, paperbound, WMO No. 819, World Meteorological Organization, ISBN 92-63-10819-6). The fifth in a series of reviews, this edition of the Global Climate System addresses climate system events during the years 1991-93, focusing on updates of El Niño-Southern Oscillation, the Mount Pinatubo eruption, and the North Atlantic Oscillation. The review encompasses the full breadth and scope of the global climate domain: atmosphere, oceans, hydrosphere, biosphere, and cryosphere. Events causing mortality, environmental degradation, and economic loss, such as floods, drought, and major storms, are well documented as are changes in the concentrations of ozone and trace gases implicated in the greenhouse gas effect.

Annual Report 1996 (1997, 61 pp., \$27.00, paperbound, WMO No. 859, World Meteorological Organization, ISBN 92-63-10859-5). This booklet covers the issues and programs of the WMO during the year 1996. Overviews of WMO's programs are provided, as well as overviews of climate change and environmental issues, WMO's finances, membership, technical assistance, and publications issued in 1996.

WMO Statement on the Status of the Global Climate in 1996 (1997, 11 pp., \$15.00, paperbound, WMO No. 858 , World Meteorological Organization, ISBN 92-6310858-7). This booklet is the fourth in the series. It fo- cuses on the status of the global climate. The information was provided by the U.S. Climate Prediction Center, with input from climate centers in Australia, Belgium, Canada, Germany, Spain, and the United Kingdom. Topics included in the booklet focus on surface temperatures in comparison to 1995 and since 1860, La Niña conditions, ozone depletion over the Northern Hemisphere, snow cover, and regional precipitation regimes.

Food Security: The Climate Factor (1996, 11 pp., $\$ 20.00$, paperbound, WMO No. 849, World Meteorological Organization, ISBN 92-63-10849-8). Within the pages of this booklet, the WMO addresses the role meteorology plays in the arena of food production. Given that 800 million people in the world are estimated to be undernourished, food security has become a priority issue with the world's policy makers. The contents of this booklet focus on WMO's Agricultural and Meteorology Programme and discuss education and training, technical cooperation of projects, mitigating the effects of drought, combating desertification, climate change and agriculture, and meteorological and hydrological hazards to agriculture.

Lectures Presented at the Twelfth WMO Congress (1997, 43 pp., \$43.00, paperbound, WMO No. 845, World Meteorological Organization, ISBN 92-6310845-5). The lectures presented at the 12th WMO congress focused on four specific themes: global warming, desertification and climate, seasonal weather forecasting, and ozone depletion and climate. The four lectures contained within this booklet address these themes and were presented by the foremost leaders in each respective field.

Guide to Meteorological Instruments and Methods of Observation. Sixth Edition (1996, 200 pp., \$155.00, spiralbound, WMO No. 8, World Meteorological Organization, ISBN 92-63-16008-2). The purpose of this guide is to establish a consistency within WMO member countries in practices for taking meteorological observations and measurements. This updated version contains three parts: measurement of meteorological variables, observing systems, and quality assurance and 
management of observing systems. (Parts II and III have yet to be issued.) All three parts contain fully revised chapters on topics treated in the fifth edition as well as new chapters not previously treated by the guide. Parts I and II contain five additional chapters. The guide describes instruments, systems, and techniques on regular use; however, it does not attempt to serve as a detailed instruction manual. The appendix contains references to national practices, to national and international standards, and to the general literature. It also includes a list of reports published by WMO for the Commission for Instruments and Methods of Observation.

\section{Publishers' Addresses}

American Meteorological Society

(WMO domestic orders only)

45 Beacon St.

Boston, MA 02108

Telephone: 617-227-2425

\section{Cambridge University Press}

- 40 W. 20 St.

New York, NY 10011

Telephone: 800-872-7423

\section{Dover Publications}

31 E. 2nd St.

Mineola, NY 11501

Telephone: 516-294-7000

\section{European Centre for Medium-Range \\ Weather Forecasts \\ Shinfield Park}

Reading/Berkshire RG2 9AX, United Kingdom

Telephone: 441189499000

\author{
Kluwer Academic Publishers \\ 101 Philip Dr. \\ Norwell, MA 02061 \\ Telephone: 617-871-6600 \\ Plenum Publishing \\ 233 Spring St. \\ New York, NY 10013 \\ Telephone: 800-221-9369 \\ Prentice Hall \\ One Lake St. \\ Upper Saddle River, NJ 07458 \\ Telephone: 800-643-5506 \\ [Code: E1001-A1(3)]
}

\author{
Southern Illinois University Press \\ P.O. Box 3697 \\ Carbondale, IL 62902 \\ Telephone: 618-453-2281
}

\section{Spectroradiometry Consulting}

P.O. Box 2747

La Plata, MD 20646

Telephone: 301-934-6364

\section{Springer-Verlag}

175 Fifth Ave.

New York, NY 10010

Telephone: 212-777-4643

Taylor \& Francis

1900 Frost Rd., Suite 101

Bristol, PA 19007

Telephone: 800-821-8312

\section{Water Resources Publications \\ 7200 East Dry Creek Rd., \\ Suite E-104 \\ Englewood, CO 80112 \\ Telephone: 800-736-2405}

\section{Whirlwind Books \\ RR3}

Elmwood, Ontario,

NOG 1 SO Canada

Telephone: 519-363-5785

\section{John Wiley \& Sons}

Distribution Center

1 Wiley Drive

Somerset, NJ 08875-1272

Telephone: 800-225-5945

World Meteorological Organization

(International orders only; domestic orders through AMS)

P.O. 2300

CH-1211 Geneva 2, Switzerland

Telephone: 41227308478 